\title{
EXAMINATION OF SPOT WELDED SEAM OF A CAR BODY
}

\author{
Andrew ANDRAWS ${ }^{1}$, Károly SZÉLL ${ }^{2}$ \\ ${ }^{1}$ Óbuda University, Bánki Donát Faculty of Mechanical and Safety Engineering, Institute of Materials and \\ Manufacturing Sciences, Department of Materials Technology Budapest, Hungary, tigris9494@hotmail.com \\ ${ }_{2}^{2}$ Óbuda University, Regia Alba Technical Faculty, Székesfehérvár, Hungary, szell.karoly@amk.uni-obuda.hu
}

\begin{abstract}
Spot welding is widely used in car industry to create a cheap and light body and chassis. Engineers tend to use spot-welding in order of reducing the production costs, also lowering the stress intensity which can cause failure and fractures of the body or chassis. Our goal here is to examine spot-welding of a car body with different tests and find out later if there is a possibility of using a different technology that can produce a better seam that can be automated with industrial robots.
\end{abstract}

Keywords: car body, spotwelding, seam examination.

\section{Introduction}

Resistance spot welding is a process in which contacting metal surface points are joined by the heat obtained from resistance to electric current. It is a subset of electric resistance welding $[1,2]$.

\section{Spot welding}

Workpieces are held together under pressure exerted by electrodes. Typically, the sheets are in the 0.5 to $3 \mathrm{~mm}$ thickness range. The process uses two shaped copper alloy electrodes to concentrate the welding current into a small "spot" and to simultaneously clamp the sheets together. Forcing a large current through the spot melts the metal and forms the weld.

\subsection{Applications}

Spot welding is usually used when welding sheet metals and wire mesh. It is harder to weld thicker metals because the heat dissipates into the surrounding metal.

The most common application of spot welding is in the vehicle manufacturing industry, being the most common method of welding the sheet metals used in the production of cars. It is also one of the two major applications of assembly line industrial robots to completely automate spot welding.

\subsection{Processing}

Spot welding is a method of welding two or more metal sheets together (without using any filler material) by applying pressure and heat to the area to be welded. The process is used for joining sheet materials and uses shaped copper alloy electrodes to apply pressure and convey the electrical current through the workpieces.

The material between the electrodes yields and is squeezed together. It then melts, removing the interface between the parts. The current is switched off and the "nugget" of molten materials solidifies forming the joint (Figures 1.).

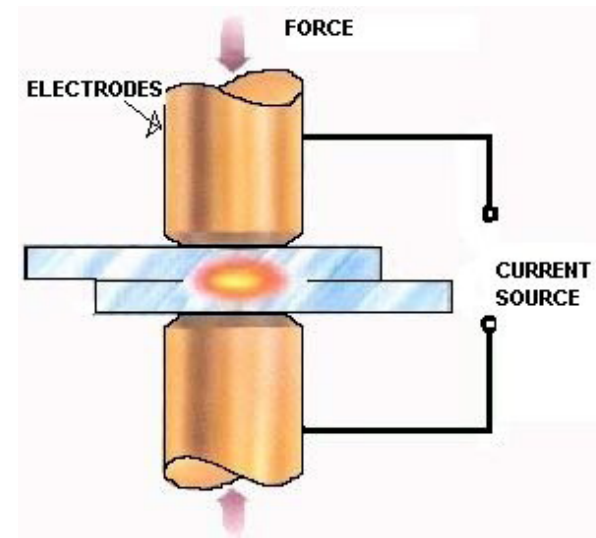

Figure 1. The principle of spot welding [2] 
The heat generated depends on the resistance and thermal conductivity of the metal and the welding time for which it flows.

The heat generated is expressed by equation:

$$
E=I^{2} \cdot R \cdot t
$$

where $E$ is the heat energy, $I$ is the current, $R$ is the electrical resistance and $t$ is the time for which the current is applied.

\subsection{Materials suitable for spot welding}

Steels are relatively easy to weld as they have a higher electrical resistance and lower thermal conductivity. For spot welding, low carbon steels are the most suitable.

\section{Preparation of the experiment}

For our experiment, the B pillar of a car was cut out and a piece of the 3 welded sheets was analysed to determine the chemical composition and types of steel that had been used in its manufacture. (Figure 2. and 3.)

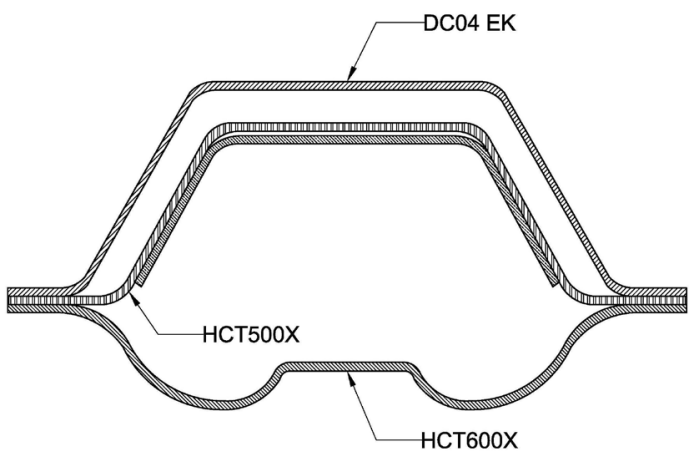

Figure 2. The cross-section of the B pillar

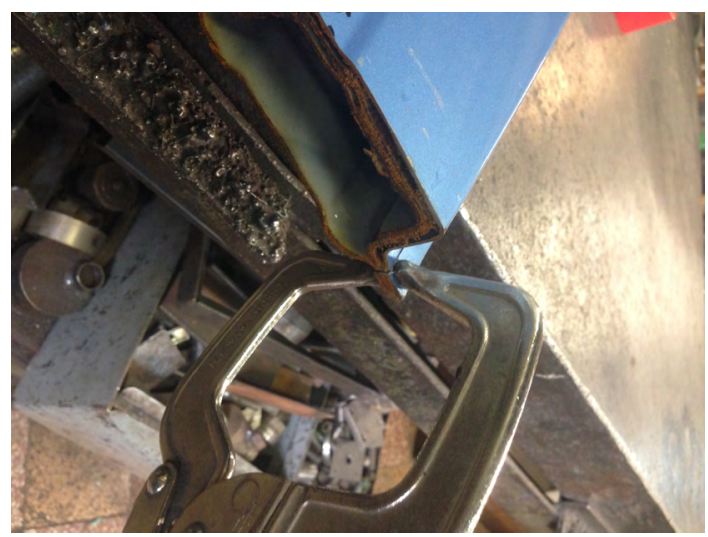

Figure 3. Cutting the samples from the B pillar for the analysis
After that the welds were mounted, a microscopic polish created and the surface was then etched to visualize the nugget and the HAZ. We then tested the hardness locally in the weld and the HAZ also in the base materials.

\subsection{Chemical composition}

By means of energy-dispersive spectroscopy, the composition of the plates was determined. The results are shown in Tables 1-3.

Based on the results we can state that the materials used were low carbon steels. Sheet 1 was a low-carbon aluminium dampened, unalloyed steel, probably because the industry prefers aluminium dampened steels when zinc-plated (Figure 3.). The low manganese content is also deoxidizing. Sheets 2 and 3 were also low carbon, dual phase alloys with manganese and silicon alloys in which the ratio of manganese to carbon was varied.

Table 1. Average chemical composition in weight percentage (\%) of DC04 EK sign steel

\begin{tabular}{|c|c|c|}
\hline \multicolumn{3}{|c|}{ DC04 EK } \\
\hline $\mathrm{C}$ & 0.04 & $\max 0.08$ \\
\hline $\mathrm{Fe}$ & 99.69 & \\
\hline $\mathrm{Mn}$ & 0.12 & \\
\hline $\mathrm{Al}$ & 0.15 & \\
\hline \multicolumn{3}{|c|}{100} \\
\end{tabular}

Table 2. Average chemical composition in weight percentage (\%) of HCT500X sign dual phase steel

\begin{tabular}{|c|c|l|}
\hline \multicolumn{3}{|c|}{ HCT500X } \\
\hline $\mathrm{C}$ & 0.14 & $\max 0.14$ \\
\hline $\mathrm{Si}$ & 0.8 & $\max 0.8$ \\
\hline $\mathrm{Mn}$ & 1.94 & $\max 2$ \\
\hline $\mathrm{Fe}$ & 97.12 & \\
\hline \multicolumn{3}{|c|}{100} \\
\hline
\end{tabular}

Table 3. Average chemical composition in weight percentage (\%) of HCT600X sign dual phase steel

\begin{tabular}{|c|c|l|}
\hline \multicolumn{3}{|c|}{ HCT600X } \\
\hline $\mathrm{C}$ & 0.17 & $\max 0.17$ \\
\hline $\mathrm{Si}$ & 0.8 & $\max 0.8$ \\
\hline $\mathrm{Mn}$ & 2.2 & $\max 2.2$ \\
\hline $\mathrm{Fe}$ & 96.8 & \\
\hline \multicolumn{2}{|c|}{100} \\
\hline
\end{tabular}




\subsection{Hardness testing}

After the identification of the materials, we can see from the microscopic section of the seam that the DC04 EK had not melted together with the other sheets where the seams are visible.

Hardness measurements were made from the beginning of the thermal zone through the seam in diagonals of 7 measurements per piece (Figure 4. and 5.).

Based on the results obtained (Diagram 1.), we found that the hardness of the sheets almost doubled on the edge of the HAZ, so at these points the sheets were harder.

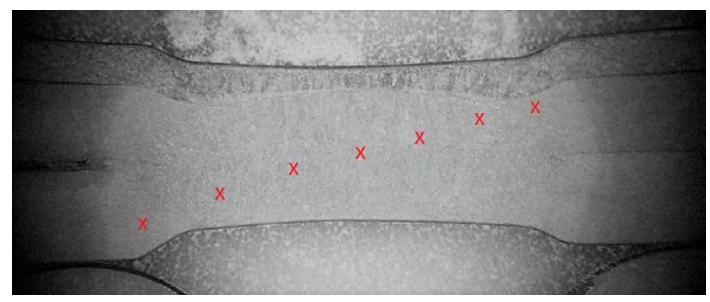

Figure 4. The boundaries of the HAZ and the nugget / Location of hardness measurements (left to right as marked on the picture)

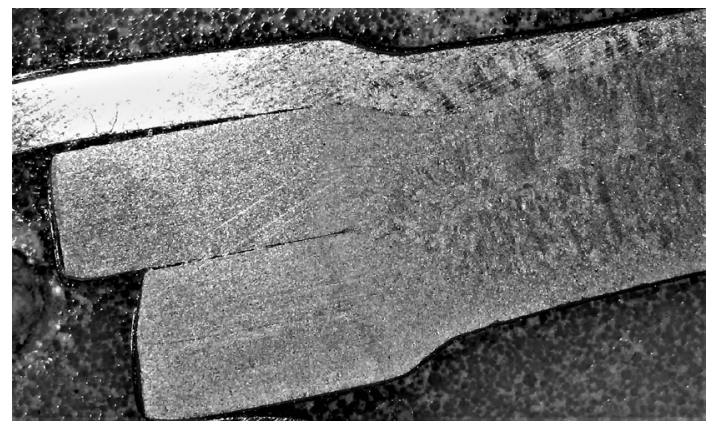

Figure 5. The section showing the welding seam

\section{Conclusions}

From the study of literature and these experimental results we conclude that:

-in the seam, the hardness of the sheets increased sharply and hardened at these points,

- the DC04 EK interface of the sheet surface had not melted during welding and this can be a problem with car body parts.

Based on the results presented, we can obtain better results by using another technology to avoid the problems we are experiencing. The technology we recommend - which can yield better results in further research and can effectively replace resistance spot welding - is laser welding, which produces a smaller HAZ and creates a better joint through experience and literary references for welding different types of sheet metals.

\section{Acknowledgements}

The authors thank Dr. Tünde Kovács and Csenge Huszák for supporting this research.

The authors hereby wish to thank for the financial support given to our work - the EFOP-3.6.1-16-201600010 project - the Hungarian State and the European Union.

\section{References}

[1] L. F. Jeffus: Welding: Principles and Applications. Cengage Learning, 2002, 694.

[2] Bagyinszki Gy., Bitay E.: Hegesztéstechnika II. Berendezések és mérések. EME kiadó, Kolozsvár, 2010.

[3] Kovács-C. T., Vajdics D.: A TRIP acél ponthegesztésének hatása. In: A XV. Műszaki tudományos ülésszak előadásai. Proceedings of the $15^{\text {th }}$ international conference of technical sciences, Cluj,

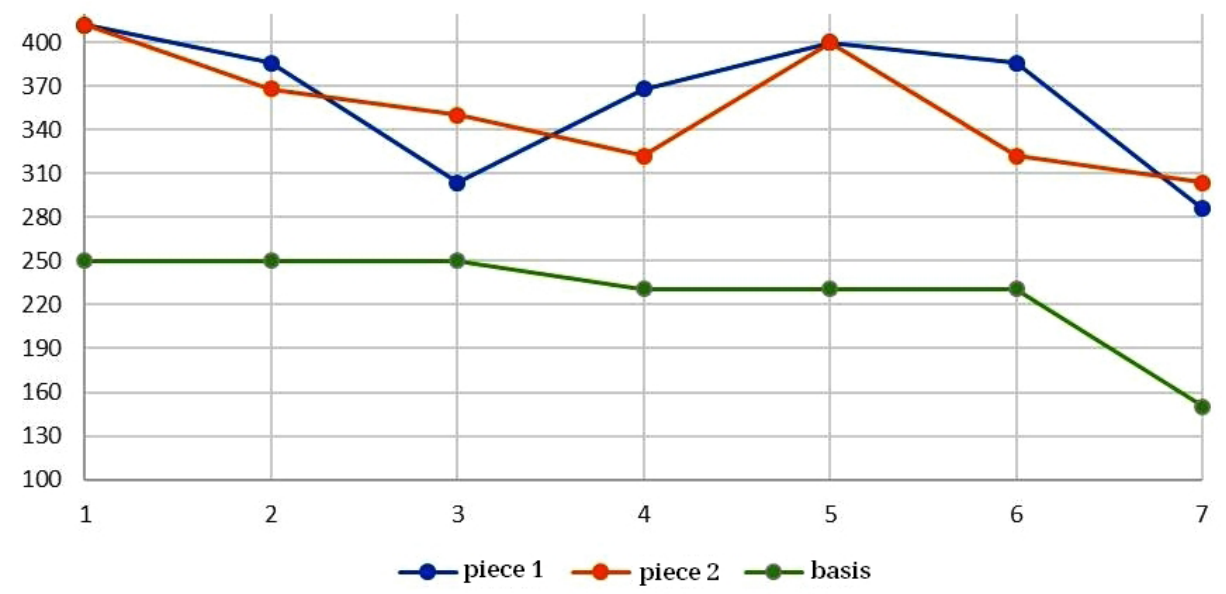

Diagram 1. The results of hardness measurement 
Romania, Műszaki Tudományos Közlemények 2. (2015) 227-234.

https://eda.eme.ro/handle/10598/28787

[4] Kovács-C. T., Bitay E.: The hardness control in the coated surface layer, Materials Science Forum 729. (2013) 415-418.

https://doi.org/10.4028/www.scientific.net/ MSF.729.415

[5] Szilágyi G., Pinke P., Kovács-C. T.: A hegesztés hatása az alapanyagra. In: Fiatal müszakiak tudományos ülésszaka XIX., Cluj, Romania, Müszaki Tudományos Füzetek 2014. 373-376.

https://eda.eme.ro/handle/10598/28284 